\title{
The level of midwifes psychopathy
}

Magdalena Chęćc PhD, Krystian Konieczny' ${ }^{1}$ Karol Karasiewicz' ${ }^{1}$ PhD, Iwona Walerczyk² ${ }^{2}$ Karolina Rachubińska ${ }^{1}$

\section{Introduction}

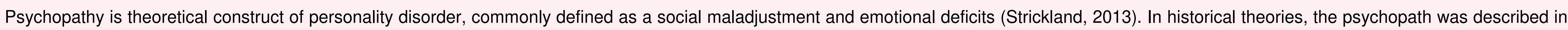

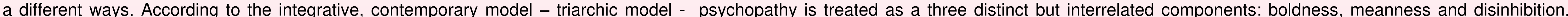

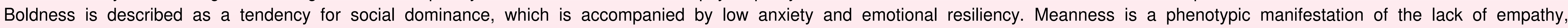

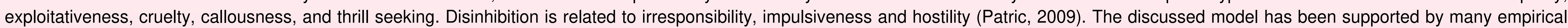

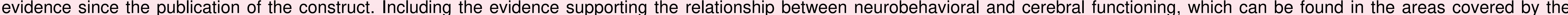

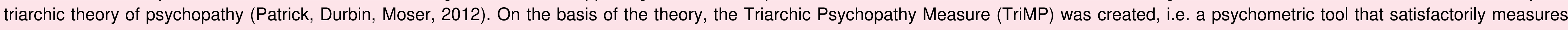

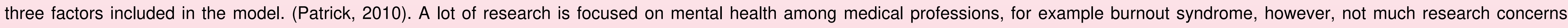
mental traits shown by employees of selected medical professions.

\section{Methodology}

The aim of this study was to measure level of midwifes psychopathy and compare it to general population. Following hypotesis was posed: Midwifes differ from general population in level of psychopathy and its factors. This study was conducted in hospitals in Szczecin, Poland using paper-and-pencil method on $n=30$ midwifes (100\% woman, aged 23-60 M=40,17; SD=13,34). Control group of general population $\mathrm{n}=89(100 \%$ woman, aged $18-45 M=28,02 ; S D=6,96)$ were examined using online survey.

The applied tool was TriMP-41 in Polish adaptation of Pilch and a self-designed questionnaire collecting sociodemographic data and information concerning the participants' professional activity.

\section{Results}

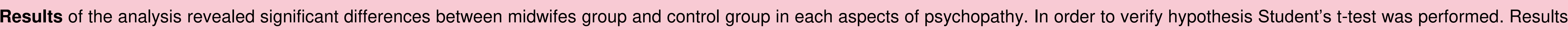

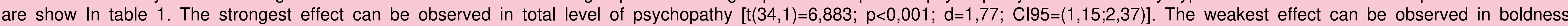

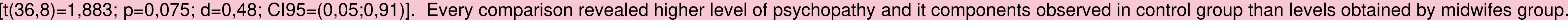
The hypothesis has been verified positively.

\begin{tabular}{|c|c|c|c|c|c|c|c|c|}
\hline \multirow{2}{*}{$\begin{array}{l}\text { Psychopathy } \\
\text { aspects }\end{array}$} & \multicolumn{2}{|c|}{$\begin{array}{l}\text { General population } \\
(\mathrm{n}=89)\end{array}$} & \multicolumn{2}{|c|}{$\begin{array}{l}\text { Midwifes } \\
(\mathrm{n}=30)\end{array}$} & \multicolumn{3}{|c|}{ Student's statistic } & \multirow[t]{2}{*}{$\begin{array}{l}\text { Cohen's } d \\
\text { effect size }\end{array}$} \\
\hline & $M$ & $S D$ & $M$ & $S D$ & $t$ & $d f$ & $p$ & \\
\hline & 53,25 & 8,08 & 36,90 & 12,14 & 6,883 & 34,1 & $<0,001$ & $\begin{array}{r}1,77 \\
(1,15 ; 2,37)\end{array}$ \\
\hline Meanness & 23,84 & 3,97 & 21,57 & 6,40 & 1,833 & 36,8 & 0,075 & $\begin{array}{r}0,49 \\
(0,05 ; 0,91)\end{array}$ \\
\hline Disinhibition & 17,04 & 5,82 & 9,63 & 4,89 & 6,83 & 58,90 & $<0,001$ & $\begin{array}{r}1,32 \\
(0,78 ; 1,85)\end{array}$ \\
\hline Boldness & 12,36 & 3,98 & 5,70 & 4,33 & 7,43 & 46,60 & $<0,001$ & $\begin{array}{r}1,64 \\
(1,03 ; 2,22) \\
\end{array}$ \\
\hline
\end{tabular}

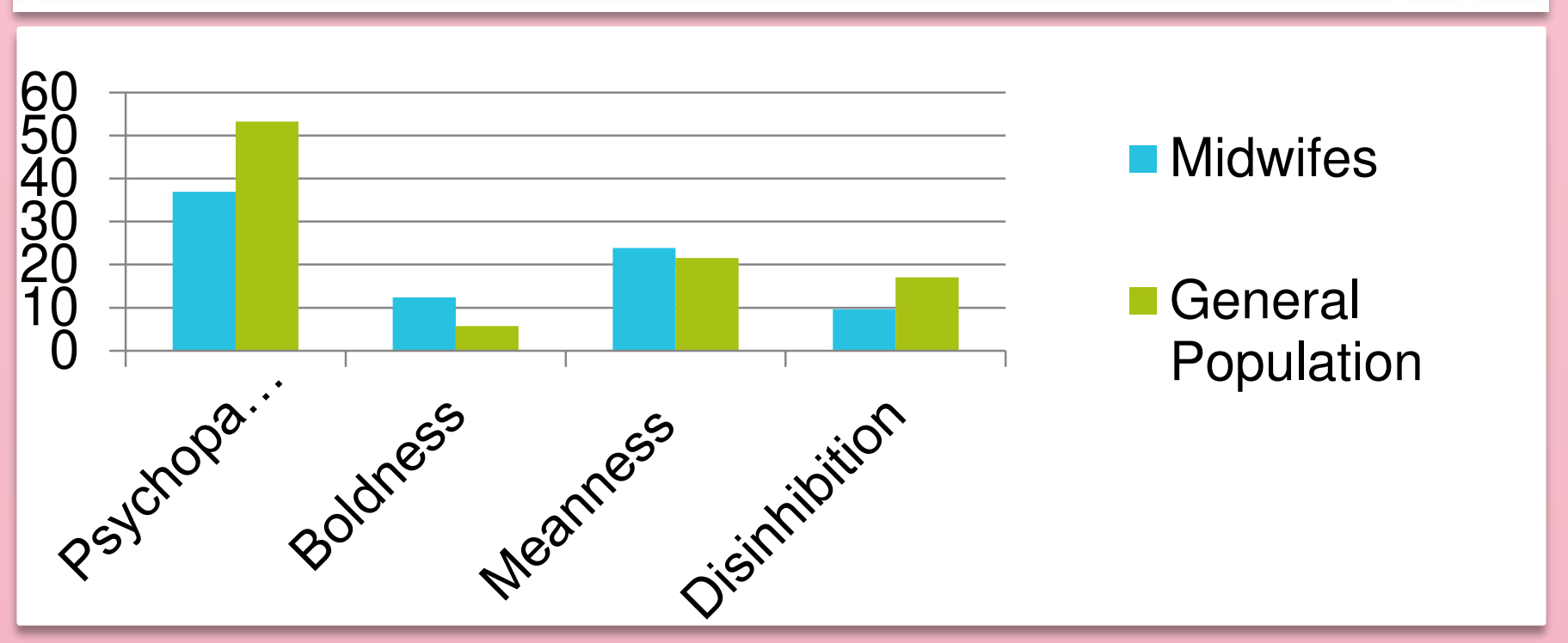

\section{Conclusion}

In summary, there are significant differences of psychopathy level and it's components between midwifes and control group. Results of this research lead to very important conclusion about health care - newborns and women in postpartum period are generally cared by midwifes who are tend to more emphatic behaviors and with less hostile, callous attitude than general population. On the other hand, midwifes level of boldness is similar to general population.

There should be considered continuing research on other occupational groups working in health care.

\section{References}

Patrick, C. J. (2010). Operationalizing the triarchic conceptualization of psychopathy: Preliminary description of brief scales for assessment of boldness, meanness, and disinhibition. Unpublished test manual.

Patrick, C. J., Durbin, C. E., \& Moser, J. S. (2012). Conceptualizing proneness to antisocial deviance in neurobehavioral terms.Devel-opment and Psychopathology,24, 1047-1071.

Patrick, C. J., Fowles, D. C., \& Krueger, R. F. (2009). Triarchic conceptualization of psychopathy: Developmental origins of disinhibition, boldness, and meanness. Development and psychopathology, 21(3), 913-938.

Strickland, C. M., Drislane, L. E., Lucy, M., Krueger, R. F., \& Patrick, C. J. (2013). Characterizing psychopathy using DSM-5 personality traits. Assessment, 20(3), 327-338. 